\title{
An evaluation of abnormal puerperium
}

\author{
Aarti Jeenwal*, Hemlata Jharbade, Nishita Singh
}

Department of Obstetrics and Gynecology, M. G. M. Medical College and M. Y. Hospital, Indore, Madhya Pradesh, India

Received: 23 January 2019

Accepted: 05 March 2019

*Correspondence:

Dr. Aarti Jeenwal,

E-mail: rtjinwal252@gmail.com

Copyright: (c) the author(s), publisher and licensee Medip Academy. This is an open-access article distributed under the terms of the Creative Commons Attribution Non-Commercial License, which permits unrestricted non-commercial use, distribution, and reproduction in any medium, provided the original work is properly cited.

\section{ABSTRACT}

Background: Puerperium is strictly defined as the period of confinement during and just after birth. It is the period following childbirth during which body tissues specially the genital organ reverts back approximately to the prepregnant state both anatomically and physiologically. At some stages some of these well-orchestrated changes can go away resulting in complications which can endanger life.

Methods: Retrospective c study was conducted in Department of Obstetrics and Gynecology of M.G.M. Medical College and M. Y. Hospitals, Indore. The cases were selected randomly from the patient who were admitted in M.Y. Hospital who had either a vaginal or caesarean delivery (both in our institution as well as outside institution) during the study period, irrespective of age, parity and registration status. Data was recorded in predesigned coded case report forms and statistical analysis was performed.

Results: Authors found that puerperal pyrexia was the most common complication, accounting for $38.96 \%$ of total cases. The second most common complication was perineal pain affecting $28.15 \%$ of cases. The other complication was wound gaping/discharge $(11.71 \%)$, mastitis and breast abscess $(6.81 \%)$, secondary postpartum hemorrhage $(5.33 \%)$, episiotomy gaping and infection $(4 \%)$, perineal hematoma $(0.59 \%)$, wound dehiscence $(0.3 \%)$ and other rare causes accounted for $4.15 \%$ of the complication.

Conclusions: Puerperal period is as important as antenatal period. Anaemia, suboptimal personal hygiene as well as improper sterilization can resulted in severe health hazards such as septicemia, disseminated intravascular coagulation as well as death. So, risk factor should be treated vigorously.

Keywords: Infection, Perineal pain, Puerperal pyrexia, Wound gaping

\section{INTRODUCTION}

Puerperium is strictly defined as the period of confinement during and just after birth. It is the period following childbirth during which body tissues specially the genital organ reverts back approximately to the prepregnant state both anatomically and physiologically. Duration of puerperium is divided into immediate up to 24 hours, early up to 7 days and late up to 6 weeks. Uterine changes just after childbirth the uterus measures around 1000 grams. The anterior and posterior walls lie in close approximation each measuring 4 to $5 \mathrm{~cm}$ in thickness. Two days after delivery uterus begins to shrink and within 2 weeks it descends to the true pelvis. $1^{\text {st }}$ week later it weighs about 500 grams at the end of $2^{\text {nd }}$ week about 300 grams and thereafter 100 grams. It regains its nonpregnant size about 4 weeks after delivery. Cervix the cervical opening contracts slowly and for a few days readily admits 2 fingers. Lochia early in the puerperium, sloughing of deciduas results in a vaginal discharge of variable quantity called lochia. Lochia persists for up to 4 weeks and may stop or resume up to 8 weeks. 
Vagina the smooth walled passage gradually diminishes in size but rarely returns to nulliparous dimensions. At some stages some of these well-orchestrated changes can go away resulting in complications which can endanger life.

Some of them are; puerperal pyrexia, puerperal sepsis, subinvolution, urinary complication, breast complication: mastitis, galactocele, breast abscess, sore nipple, puerperal venous thrombosis, obstetric palsies, puerperal emergencies, psychiatric disorder occurrence by being vigilant, early ambulation and to treat them as early after detection using antibiotics, physiotherapy, other drugs, support etc. The puerperal sepsis/pyrexia presents commonly with fever and other symptoms like pelvic pain, foul smelling vaginal discharge and delayed reduction of the uterine size. ${ }^{1}$ World literature search revealed a Nigerian study report that puerperal sepsis is a second leading cause of death accounting for $26.3 \%$ of maternal deaths, while another WHO report estimated 358,000 maternal deaths yearly occurring due to child birth problems and out of these up to $15 \%$ are associated with puerperal sepsis. . $^{2,3}$

\section{METHODS}

The present study was carried out in the department of Obstetrics and Gynecology, M.G.M. Medical college and M.Y. hospital Indore. It is a retrospective randomized study. The study period from 1 September 13 to March 2014

\section{Selection of cases}

The cases were selected randomly from the patient who were admitted in M.Y. Hospital who had either a vaginal or caesarean delivery (both in our institution as well as outside institution) during the study period, irrespective of age, parity and registration status. On a specially designed proforma, the patient's particulars, detailed obstetric history, examination and laboratory finding were recorded. Total of 4955 deliveries took place in the study period and among them 675 puerperal complication occurred.

\section{Inclusion criteria}

- Only institutional deliveries were included

- Cases were taken irrespective of registration status.

\section{Essential criteria}

- Patient delivered in or outside MYH <6 weeks postpartum.

The complication included in the study were: Puerperal pyrexia, pain, breast abscess and mastitis, episiotomy infection and gaping, caesarean wound infection and gaping, wound dehiscence and burst abdomen secondary PPH. Other rare complication-puerperal psychosis, pelvic abscess, peritonitis, inversion was included. In each case urine albumin, $\mathrm{Hb}$, blood sugar was done routinely. Other specific investigation like vaginal swab culture, urine and blood culture, USG abdomen and pelvis, pus culture etc. were done where indicated.

\section{RESULTS}

In present study, maximum incidence of puerperal complication occurred in nulliparous women (16.25\%) and those who belongs to lower socioeconomic status. It indicates that nulliparity and poor hygiene is a risk factor for puerperal complication to developed (Table 1).

Table 1: Distribution of cases according to parity wise and socioeconomic status.

\begin{tabular}{|l|l|l|l|}
\hline $\begin{array}{l}\text { Sociodemographic } \\
\text { characteristic }\end{array}$ & & $\begin{array}{c}\text { Number } \\
\text { of cases } \\
(\mathbf{n = 6 7 5 )}\end{array}$ & Percentage \\
\hline \multirow{5}{*}{ Parity } & P0 & 388 & 16.25 \\
\hline & P1 & 212 & 13.37 \\
\hline & P2 & 61 & 8.10 \\
\hline & P3 & 12 & 6.69 \\
\hline \multirow{2}{*}{ Religion } & P4 & 2 & 3.33 \\
\hline \multirow{2}{*}{ Socioeconomic } & Hindu & 392 & 58.1 \\
\hline \multirow{2}{*}{ status } & Muslim & 283 & 41.9 \\
\hline \multirow{2}{*}{ Geographic area } & Class I & 18 & 6.73 \\
\hline & Class II & 36 & 7.48 \\
\hline & Class III & 74 & 10.69 \\
\hline & Class IV & 204 & 13.60 \\
\hline & Class V & 343 & 17.03 \\
\hline & Urban & 446 & 66.07 \\
\hline
\end{tabular}

In this study, authors found that the incidence of puerperal complication in our hospital was $13.63 \%$. the incidence of puerperal complication was significantly higher $(22.41 \%)$ in caesarean section group as compared to vaginal deliveries $(11.36 \%)$ (Table 2$)$.

Table 2: Incidence of puerperal complication during the study period.

\begin{tabular}{|c|c|c|c|}
\hline & No. & Complication & Incidence \\
\hline Total deliveries & 4955 & 675 & $13.63 \%$ \\
\hline Vaginal deliveries & 3935 & 447 & $11.36 \%$ \\
\hline $\begin{array}{l}\text { Ceasarean } \\
\text { deliveries }\end{array}$ & 1020 & 228 & $22.41 \%$ \\
\hline $\begin{array}{l}\text { Total mortality } \\
\text { of complication }\end{array}$ & 07 & \multirow{3}{*}{ - } & \multirow{3}{*}{$1.04 \%$} \\
\hline Vaginal delivery & 04 & & \\
\hline $\begin{array}{l}\text { Caesarean } \\
\text { delivery }\end{array}$ & 03 & & \\
\hline
\end{tabular}

In this study, of patient who presented with puerperal complication, 14 patient succumbed to ill-effects, giving an incidence maternal morality following puerperal complication to be $1.04 \%$. (Table 1). In present study, 
authors found that puerperal pyrexia was the most common complication, accounting for $38.96 \%$ of total cases. The second most common complication was perineal pain affecting $28.15 \%$ of cases. The other complication was wound gaping/discharge (11.71\%), mastitis and breast abscess (6.81\%), secondary postpartum hemorrhage $(5.33 \%)$, episiotomy gaping and infection $(4 \%)$, perineal hematoma $(0.59 \%)$, wound dehiscence $(0.3 \%)$ and other rare causes accounted for $4.15 \%$ of the complication (Table 3 ).

Table 3: Distribution of types of puerperal complication $(n=675)$.

\begin{tabular}{|l|l|l|}
\hline $\begin{array}{l}\text { Puerperal } \\
\text { complication }\end{array}$ & $\begin{array}{l}\text { Number of } \\
\text { cases }\end{array}$ & Percentage \\
\hline Puerperal pyrexia & 263 & 38.96 \\
\hline Perineal pain & 190 & 28.15 \\
\hline Wound gaping & 79 & 11.71 \\
\hline mastitis & 46 & 6.81 \\
\hline Secondary PPH & 36 & 5.33 \\
\hline Miscellaneous & 28 & 4.15 \\
\hline $\begin{array}{l}\text { Episiotomy gaping and } \\
\text { infection }\end{array}$ & 27 & 4 \\
\hline Perineal hematoma & 4 & 0.59 \\
\hline Wound dehiscence & 2 & 0.3 \\
\hline
\end{tabular}

From Table 4, it is clear that the only $12.49 \%$ of nonanaemic patients had puerperal complication compared to $20.72 \%$ of mildly anaemic, $23.34 \%$ of moderately anaemic, and $22.73 \%$ of severely anaemic patients.

Table 4: Association of complication with the degree of anaemia.

\begin{tabular}{|l|l|l|l|}
\hline $\begin{array}{l}\text { Haemoglobin } \\
\text { status }\end{array}$ & $\begin{array}{l}\text { No. of } \\
\text { patients }\end{array}$ & $\begin{array}{l}\text { No. of } \\
\text { cases }\end{array}$ & Percentage \\
\hline $\begin{array}{l}7-8 \text { (Moderate } \\
\text { anaemic) }\end{array}$ & 287 & 67 & 23.34 \\
\hline$<7$ (Severe) & 66 & 15 & 22.73 \\
\hline \begin{tabular}{l} 
8-10 (Mild) \\
\hline $\begin{array}{l}>10(\text { Non }- \\
\text { anaemic) }\end{array}$
\end{tabular} & 222 & 46 & 20.72 \\
\hline
\end{tabular}

From Table 5, it is clear that in the vaginally delivered cases, perineal pain was the most common complication accounting for $42.55 \%$ followed by puerperal pyrexia $36.95 \%$, episiotomy gapping and infection $6.05 \%$, secondary postpartum hemorrhage $5.38 \%$, mastitis and breast abscess $4.14 \%$, perineal hematoma $0.9 \%$ and other rare causes $3.92 \%$.

Table 5: Incidence of various puerperal complication following vaginal and caesarean delivery.

\begin{tabular}{|c|c|c|c|c|}
\hline \multirow{2}{*}{ Puerperal complication } & \multicolumn{2}{|c|}{ Vaginally delivery ( $n=447)$} & \multicolumn{2}{|c|}{ Caesarean delivery $(\mathrm{n}=228)$} \\
\hline & Number of cases & Percentage & Number of cases & Percentage \\
\hline Puerperal pyrexia & 165 & 36.95 & 98 & 42.67 \\
\hline Perineal pain & 190 & 42.55 & NA & NA \\
\hline Wound gaping & NA & NA & 79 & 34.57 \\
\hline mastitis & 18 & 4.14 & 27 & 12.04 \\
\hline Secondary PPH & 24 & 5.38 & 12 & 5.25 \\
\hline Miscellaneous & 17 & 3.92 & 11 & 4.6 \\
\hline Episiotomy gaping and infection & 27 & 6.05 & NA & NA \\
\hline Perineal hematoma & 4 & 0.59 & NA & NA \\
\hline Wound dehiscence burst abdomen & NA & NA & 2 & 0.88 \\
\hline
\end{tabular}

In caesarean cases, puerperal pyrexia was the most common complication accounting for $42.67 \%$ of cases, followed by wound gapping and infection $34.57 \%$, mastitis and breast abscess $12.04 \%$, secondary postpartum haemorrhage $5.25 \%$, wound dehiscence $0.88 \%$ and other rare causes accounted for $4.6 \%$ of the cases (Table 4). In present study, authors found that the incidence of puerperal complication was significantly higher in unbooked $(14.78 \%)$ than in booked cases $(10.71 \%)$ and more in referred cases $(70.59 \%)$ than in non-referred $(8.87 \%)$.

Table 6 indicates that maximum number of complication (74.45\%) occurred in the first 3 postnatal days, indicating for more vigilant management of patient during the early postnatal days. In present study authors also found that $61.22 \%$ cases of puerperal pyrexia were associated with meconium stained amniotic fluid indicating that MSL is a high-risk factor for puerperal pyrexia.

Table 6: Distribution according to postnatal day at which complication were evident.

\begin{tabular}{|l|r|l|}
\hline Post-natal day & Number of cases & Percentage \\
\hline Day 1 & 138 & 20.37 \\
\hline Day 2 & 173 & 25.52 \\
\hline Day 3 & 193 & 28.52 \\
\hline Day 4 & 91 & 13.59 \\
\hline Day 5 or more & 81 & 12.00 \\
\hline Total & 675 & 100.00 \\
\hline
\end{tabular}


In present study, maximum number of cases were managed medically $88.74 \%$.

\section{DISCUSSION}

Severe puerperal sepsis is a known source of severe maternal morbidity and mortality in developing nations like India. ${ }^{4}$ Prophylactic antibiotics during operation reduces endometritis by $66-75 \%$ and also reduces rate of wound infection. ${ }^{5}$ The infection control measures requires proper education, improvements of guidelines and various technologies and introduction of new clinical guidelines. ${ }^{6}$ In present study incidence of complication in cases of vaginal deliveries was $11.35 \%$ and that in cases with caesarean deliveries was $22.44 \%$. this show that there are more complication following surgical delivery. Burrow et al, in 2004 reported that route of delivery is the single most important factor for development of uterine infection. $^{7}$ Yokoe et al, found $0.8 \%$ incidence of endometritis after caesarean deliveries and $0.2 \%$ after vaginal deliveries. ${ }^{8}$ Puerperal pyrexia was most common complication followed by pain. According to Brig and associates reported the result from pregnancy mortality surveillance system, which contained 3201 maternal death in United States from 1991 to 1997, infection made up $13 \%$ of pregnancy related death. Along with preeclampsia and obstetrics hemorrhage puerperal infection formed the lethal causes of maternal death in $20^{\text {th }}$ century. This explains that puerperal infection (pyrexia) must be most common complication. The incidence of wound gaping and discharge was $11.70 \%$ which is concordance with Owen and Andrews 1994 and Chaim associates 2004, they found incidence of abdominal incisional infection following caesarean section ranges from 3-15\% with an average of about $6 \% .^{9}$ According to Andrews and colleagues in 2003 , with prophylactic antimicrobials the incidence is less than $2 \% .{ }^{10}$ Incidence of wound dehiscence was $0.26 \%$ which is concordance with Mc Neeley and colleagues. ${ }^{11}$ Authors found incidence of perineal hematoma to be $0.59 \%$. Cunningham et al found incidence of puepral hematoma varies from $0.66 \%$ to $0.01 \%$. Table show that in vaginal delivered cases, perineal pain was the most common followed by pyrexia. But according to a study in Nigeria the commonest complication following vaginal delivery was fever, perineal pain and abdominal pain. Puerperal complication is more common in unbooked case which show that good antenatal care is necessary for a healthy outcome.

Funding: No funding sources Conflict of interest: None declared

Ethical approval: The study was approved by the Institutional Ethics Committee

\section{REFERENCES}

1. van Dillen J, Zwart J, Schutte J, van Roosmalen J. Maternal sepsis: epidemiology, etiology and outcome. Current Opinion Infectious Dis. 2010;23(3):249-54.

2. BM Audu, UI Takai, M Buker. Trends in maternal mortality at university of Maiduguri teaching hospital, Maiduguri Nigeria-A five years review. 2010;51(4):147-51.

3. World Health Organization: Trends in maternal mortality 1990-2008. Estimates developed by WHO, UNICEF, UNFPA and World Bank, Geneva; 2010. Available

at: https://apps.who.int/iris/bitstream/handle/10665/444 23/9789241500265_eng.pdf;jsessionid=0E1A427212 2C034F59575F65375287BC?sequence $=1$.

4. Khaskheli MN, Baloch S, Sheeba A. Risk factors and complications of puerperal sepsis at a tertiary healthcare centre. Pak J Med Sci. 2013;29(4):972-76.

5. Smail FM, Gyten GM. Antibiotic prophylaxis versus no prophylaxis for preventing infection after cesarean section. Cochrane Database Syst Rev. 2010;(1):CD007482.

6. Larson EL, Quiros D, Lin SX. Dissemination of CDC, S Hand Hygiene Guideline and impact on infection rates. Am J Infect Control. 2007;35(10):666-75.

7. Brown CE, Stettler RW, Twickler D, Cunningham FG. Puerperal septic pelvic thrombophlebitis: incidence and response to heparin therapy. Am J Obstet gynecol. 1999;181(1):143-8.

8. Yokoe DS, Christiansen CL, Johnson R, Sands KE, Livingston J, Shtatland ES, et al. Epidemiology of and surveillance for postpartum infections. Emerging Infectious Dis. 2001;7(5):837.

9. Owen J, Andrews WW. Wound complications after cesarean sections. Clinical Obstet Gynecol. 1994;37(4):842-55.

10. Andrews WW, Hauth JC, Cliver SP, Savage K, Goldenberg RL. Randomized clinical trial of extended spectrum antibiotic prophylaxis with coverage for Ureaplasma urealyticum to reduce postcesarean delivery endometritis. Obstet Gynecol. 2003;101(6):1183-9.

11. Mc Neeley Jr SG, Hendrix SL, Bennett SM, Singh A, Ransom SB, Kmak DC, Morley GW. Synthetic graft placement in the treatment of fascial dehiscence with necrosis and infection. Am J Obstet Gynecol. 1998;179(6):14.

Cite this article as: Jeenwal A, Jharbade H, Singh N. An evaluation of abnormal puerperium. Int J Reprod Contracept Obstet Gynecol 2019;8:1491-4. 